\title{
Лариса Шпаковская
}

\author{
Charlie Walker and Steven Roberts, eds. Masculinity, Labour, and Neoliberalism: \\ Working-Class Men in International Perspective. Basingstoke, UK: Palgrave Mac- \\ millan, 2018. 338 pp. ISBN 978-3-319-63171-4.
}

\begin{abstract}
Лариса Шпаковская - доцент Национального исследовательского университета Высшая школа экономики (Санкт-Петербург). Адрес для переписки: Московский nр., 73, корп. 5, кв. 869, Санкт-Петербург, 196084, Россия. lshpakovskya@hse.ru.
\end{abstract}

Современные работы, анализирующие гендерные отношения, сходятся на том, что «традиционная» мужественность претерпевает существенные изменения. Исследователи обращают внимание на ситуацию «заблокированной гендерной революции» (Hochschild 1989), когда кардинальное изменение ролей женщин не сопровождается соответствующими изменениями гендерных ролей мужчин, идентичность которых по-прежнему выстраивается вокруг профессиональных ролей в публичной сфере, а также роли добытчика в семье. «Разгневанные белые мужчины» испытывают чувство фрустрации, поскольку все так же выполняют свою традиционную гендерную роль, но при этом больше не получают привилегий, которые она дает (Темкина 2018). Они становятся заметными акторами современности. «Злые мужчины» в бедных штатах США голосуют против социально ориентированных политиков (Hochschild 2016). Они выступают против тех, кто, как им кажется, отнимает их привилегии: женщин, гомосексуалистов, мигрантов. Фрустрация оборачивается насилием как в приватной, так и публичной сферах (Kimmel 2013). Всем, кто хочет разобраться в том, что происходит с «традиционной» мужественностью в современном мире, можно порекомендовать книгу «Masculinity, Labour, and Neoliberalism: Working-Class Men in International perspective», выпущенную под редакцией известных исследователей маскулинности Чарли Уолкера (Charlie Walker) (Университет Саусхемпшира, Великобритания) и Стивена Робертса (Steven Roberts) (Университет Монаша, Австралия), в которой процессы трансформации гегемонной маскулинности рассматриваются в глобальной перспективе сквозь призму класса, расы, этничности и возраста.

Книга посвящена исследованию маскулинности рабочего класса, идентичность и социальное признание которого строились на физической силе, выносливости, автономии, солидарности, коллективном противостоянии. Именно такие черты физической силы, агрессивности, навыки мужской дружбы еще недавно ассоциировались с гегемонной маскулинностью (Connell 1987). Однако эти культурные идиомы мужественности подрываются структурными экономическими изменениями, которые происходят в конце XX - начале XXI веков. Эти изменения включают процессы упрощения и специализации труда, исчезновение традиционных форм ученичества (передачи мастерства и навыков работы), усложнения менеджериального контроля и бюрократизации корпоративного управления, возникновение понятия карьеры как индивидуального проекта. 
Издание представляет собой сборник статей, авторы которых публикуют результаты эмпирических исследований маскулинности представителей рабочего класса в различных регионах мира: Нигерии, Великобритании, Швеции, Финляндии, России, Греции, Австралии, США. Всего в книге 14 глав. Несмотря на то, что главы посвящены анализу очень различных локальных контекстов маскулинности, они, как мозаика, составляют общую картину через наложение аналитических линз интерсекциональности.

Процессы, связанные с развитием постиндустриальной экономики в странах первого мира (таких как Великобритания, США, скандинавские страны), привели к упадку статуса и символическому “обнищанию” ручного труда и физической силы, составлявших основу рабочей гордости в индустриальной экономике. Другие регионы переживали упадок ручного труда в результате деиндустриализации и экономического кризиса в этих странах. В частности коллапс Советского Союза привел к закрытию производств, сокращению уровня оплаты труда в индустриальных секторах экономики, социальной незащищенности их работников. Одновременно, вследствие проникновения на российский рынок международных корпораций, появлялись новые производства. Они предлагали более престижную и хорошо оплачиваемую работу, но на условиях более строго контроля, интенсивного и продолжительного режима труда (см. главу 9 рецензируемого издания, написанную Адександриной Ваньке (Alexandrina Vanke)).

В новой экономике изменился и сам характер работы «синих воротничков». Труд рабочих становится все менее автономным и все более подчиняемым внешнему контролю. Так, глава 13, написанная финским социологом Тимо Ахо (Timo Aho), посвящена исследованию профессионального опыта и идентичности водителей-дальнобойщиков в Финляндии. Традиционно эта профессия ассоциировалась с героической маскулинностью рабочего класса, автономией, свободой и риском. Однако автономия оказалась подорвана системами технического мониторинга, направленными на облегчение менеджериального контроля работы дальнобойщиков. Общим следствием деиндустриализации и развертывания новой экономики во всем мире стали подрыв гегемонной маскулинности рабочего класса и придание ей статуса маскулинности маргинализированной, проблемной, лишенной символической и экономической поддержки.

Процессы технологических изменений труда вписаны в неолиберальную идеологию. Ее основной посыл состоит в передаче ответственности индивидам за свою жизнь, свои удачи и поражения. Фактически либеральная идеология легитимирует и деполитизирует социальные неравенства. Бедные и социально пассивные обвиняются в своем положении, поскольку они мало работали, были недостаточно умны и в результате не смогли достичь социально приемлемого уровня материального благосостояния. Рабочий класс во всем мире потерял свои позиции при неолиберальной экономической политике. Он оказался одним из лузеров неолиберализма (глава 1).

Потеря социальных позиций в публичной сфере ставит под сомнение позиции рабочих в приватности в качестве добытчиков и сильных кормильцев. Они оказываются зажатыми между двумя типами требований в ситуации «незавер- 
шенной гендерной революции». Общество по-прежнему ожидает от мужчины демонстрации традиционных атрибутов успешности. При этом производственных и экономических оснований для такого типа маскулинности становится все меньше. В рамках гендерной системы рабочие теряют гегемонные позиции, лишаются своего прежнего статуса. Позиции гегемонной маскулинности занимают представители среднего класса.

Книга кажется крайне важной для исследований маскулинности, поскольку ее авторы, изучая «проблемную» маскулинность рабочего класса, последовательно деконструируют основания этой проблемности и маргинальности. Они анализируют различные сферы и социальные институты, которые маргинализируют рабочих, а также обращают внимание на их попытки преодолеть маргинальность и адаптироваться к новой экономике, найти новые основания для социальной гордости и самоуважения. Книгу отличает последовательная позиция авторов, связанная с преодолением стигматизации рабочих и развенчанием расхожих конвенций обсуждения проблем рабочего класса.

Выделяя труд, его условия и социальную организацию в качестве центральной сферы производства классового статуса рабочих, авторы также рассматривают другие инструменты их маргинализации: символические репрезентации, образование, потребление, семью. В частности символические репрезентации в массовой культуре, официальном и экспертном дискурсе часто представляют рабочих как проблему, источник опасности и социального беспорядка. 0 них говорят как о склонных к жестокости, преступности, алкоголизму, семейному насилию, расизму, ксенофобии. При этом рабочие нередко представляются как герои либерализма. Массовая культура склонна показывать рабочего как self-made man, умеющего делать тяжелую работу и отрицающего материальные блага. Однако фактически эта идеализированная и деполитизированная маскулинность «синих воротничков» производится как зрелище для потребления средним классом.

Авторы изучают, как различные типы дискурсов маргинализируют рабочих. Глава 3 (написанная Никсоном Дарреном (Darren Nixon)) показывает, что молодые рабочие в условиях сервисной экономики с трудом находят работу, сталкиваются с безработицей и бедностью. При этом в рамках официального дискурса реформ социального обеспечения они предстают как угроза социетальным ценностям и препятствие для успешной реализации реформ, поскольку не способны взять на себя ответственность за собственное благосостояние. Глава 14 (авторы которой Стив Робертсон, Брэндан Гоф и Марк Робинсон (Steve Robertson,Brendan Gough, Mark Robinson)) посвящена анализу показателей здоровья мужчин из рабочего класса в Великобритании. Ее авторы приходят к выводу о том, что официальный дискурс в рамках социальной политики представляет мужчин-рабочих как склонных к рисковому поведению, отказывающихся следить за состоянием своего здоровья, при этом игнорируются условия их жизни и работы.

Либеральная идеология, воплощенная в дискурсах борьбы с бедностью, представляет индивидов как ответственных за свое социальное поражение. На уровне субъективности эти дискурсы болезненно переживаются молодыми людьми, которые не способны воплотить идеалы социального успеха и материального 
благополучия. Они развивают различные формы символического сопротивления, превращая стигматизирующие их качества в преимущества, например, через участие в уличной преступности, накопление «уличного капитала», культ физической силы, которые дают им основания для самоуважения. Вместе с тем, несмотря на «протестную маскулинность», они разделяют идеалы «нормальной» мужественности, такие как наличие постоянной работы, семья и отцовство (глава 4).

Образование представляет, возможно, одну из наиболее очевидных сфер производств вторичного статуса «синих воротничков». Дети из рабочих семей повсеместно оказываются менее успешными в системе образования: они проводят меньше времени внутри системы, демонстрируют более низкие показатели академической успеваемости по сравнению с выходцами из семей среднего класса. При этом есть гендерная диспропорция участия в образовании учащихся из семей рабочих. Девочки из рабочих семей более успешны в образовательной системе, чем мальчики (глава 6). Исследователи показывают, что обычно юноши из рабочих семей разделяют культурные коды рабочей маскулинности: физическая сила, отрицание авторитета учителей, дисциплины и школьных правил. Все эти вещи подвергаются вытеснению и маргинализации в форме буллинга, дистанцирования со стороны успешных учащихся и учителей (глава 7, написанная Тони Косонен (Toni Kosonen)). Майкл Вард (Ward, Michael R. M.) в 6 главе изучает случаи успешных учащихся из рабочей среды в школьной системе Великобритании. Успешность обеспечивает отказ от рабочей маскулинности в пользу осуществления гендерного перформанса маскулинности, одобряемой школой.

Семья становится сферой жизни, где мужчины из рабочего класса, с одной стороны, испытывают маргинализацию (с точки зрения их привлекательности в качестве брачных партнеров), а с другой стороны - семья дает возможности социального реванша через отношения доминирования и подчинения по отношению к женщинам и детям. В частности глава 2 (автор Колетт Харрис (Colette Harris)) посвящена изучению положения мужчин из рабочей среды в Нигерии. Автор показывает, что традиционно в Нигерии статус мужчин строился через контроль над собственностью и материальными ресурсами, однако глобальная экономика разрушила эти основания. Чернокожие мужчины ощущают свой вторичный статус по сравнению с белыми мужчинами. Доминирование в семье и семейное насилие становятся для них возможностью восстановления гендерной гегемонии.

Потребление можно рассматривать как деятельность, в рамках которой мужчины, принадлежащие рабочему классу, стремятся компенсировать и преодолеть свой маргинализированный статус. В частности рисковое поведение, агрессивность, сексизм, чрезмерное потребление алкоголя выступают такими практиками статусного реванша на основе традиционной маскулинности рабочих за пределами тех институтов, где эта маскулинность ставится под сомнение, прежде всего за пределами работы и места учебы. При этом потребление может быть основой и для позитивного преодоления маргинального статуса. Так, владение автомобилем и навыки его техобслуживания являются основаниями для конструирования гомосоциального сообщества рабочих на основе физической силы и технического 
мастерства. «Гаражная культура» выступает способом поддержания маскулинного статуса рабочих в условиях потери других оснований для социальной гордости и взаимной кооперации в российском провинциальном городе (см. главу 8, написанную Джереми Моррисом (Jeremy Morris)). Потребление также может выступать способом «маскировки» рабочей маргинализированной маскулинности. Так, Александрина Ваньке (в главе 9) показывает, что молодые рабочие в России стараются скрыть свою профессиональную принадлежность, инвестируя свои ресурсы во внешний вид, личное развитие, покупку дорогой одежды, имитируя внешность и стиль жизни среднего класса.

Таким образом, анализируя различные контексты маскулинности, авторы книги показывают, как трансформация экономических и политических условий существования рабочего класса подрывает материальные и культурные основания «традиционной» мужественности. Успешные способы преодоления вторичного статуса в большинстве случаев связаны с отказом от культурных образцов рабочей маскулинности в пользу маскулинности среднего класса (через принятие культуры школьного обучения или потребительские образцы среднего класса). При этом во многих случаях мужчины-рабочие не имеют достаточных ресурсов для достижения стандартов маскулинности среднего класса. В условиях либеральной политики и идеологии они оказываются вне социального признания: бедными, безработными, обузой для социального государства, проблемой для школьных учителей и менеджеров корпораций.

\section{СПИСОК ЛИТЕРАТУРЫ}

Темкина, Анна. 2018. «0 злых белых мужчинах». ЕУСПб. Хроника. Просмотрено 2 ноября 2018 г. (https://eu.spb.ru/news/19055-anna-temkina-o-zlykh-belykh-muzhchinakh?fbclid=IwAR1R RmjzkDQZTTis5qCy0dfs9uc3sKmL4mmvs04NxvgKvh4jQnh1012TZas).

Connell, R. W. 1987. Gender and Power: Society, the Person, and Sexual Politics. Stanford, CA: Stanford University Press.

Hochschild, Arlie Russel. 1989. The Second Shift: Working Families and the Revolution at Home. New York: Viking.

Hochschild, Arlie Russel. 2016. Strangers in Their Own Land: Anger and Mourning of the American Right. New York: New Press.

Kimmel, Michael. 2017. Angry White Men: American Masculinity at the End of an Era. New York: Nation Books. 